\title{
The 'Frozen' Heart of the Continent: Place-Myths and Winnipeg in Canadian Crime Films
}

James Gacek

University of Edinburgh
Steven Kohm

University of Winnipeg

Within Canadian national cinema, audiences view places that draw attention to the shared experience of being within these geopolitical, socio-spatial locations. This paper contends that crime films set in Winnipeg, a city situated in the centre of North America, reflect and contribute to the cultural identity of the city within the national imaginary. Place-myths have the potential to construct meanings about a particular place, indicating whether it is romantic or dangerous, progressive or "backward," vibrant or decaying. While currently branded by local civic boosters as the 'Heart of the Continent,' (Kives, 2008) the construction of Winnipeg-asplace on film tells a different tale. By implementing a qualitative media analysis, we argue that place-myths manifest themselves within Canadian crime film narratives, and that a better understanding of place allows us to observe how Winnipeg becomes socially spatialized onscreen. As our paper suggests, one's sense of space can only constellate when one's experiences of being and acting within a place is taken into account. Winnipeg ultimately becomes represented on film as a place where crime is rampant and law enforcement is unable to combat the criminal behaviour within the city - in other words, where law and justice is 'frozen.'

Keywords: Place-myths; crime; film; space; Winnipeg

Dans le cinéma national canadien, les auditoires vont associer les lieux avec leur propre expérience de ces emplacements géopolitiques et de leur espace social. Cet article soutient que les films policiers qui se déroulent à Winnipeg, une ville située au centre de l'Amérique du Nord, reflètent et contribuent à forger l'identité culturelle de la ville au sein de l'imaginaire national. Les mythes liés aux endroits ont le potentiel de construire des significations autour d'un lieu spécifique, indiquant si cet espace est romantique ou dangereux, progressif ou « rétrograde », animé ou déserté. Même si des représentants de Winnipeg vont qualifier la ville de « cœur du continent » (Kives, 2008), sa construction imaginaire au cinéma raconte une autre histoire. Par la mise en œuvre d'une analyse qualitative des médias, nous soutenons que les mythes des lieux se manifestent dans les trames narratives des films policiers canadiens, et qu'une meilleure compréhension des lieux nous permet de constater comment l'espace social de Winnipeg a été présenté à l'écran. Comme notre article le suggère, notre perception de l'espace ne peut s'exprimer pleinement que si nous expérimentons concrètement et agissons dans celui-ci. Winnipeg devient finalement représenté au cinéma comme un endroit où le crime est à la hausse et les organismes d'application de la loi incapables de combattre les comportements criminels dans la ville - en d'autres mots, où la loi et la justice sont « immobiles ».

Mots clés: mythes; crime; filme; Winnipeg 
As a cultural medium, films both reflect dominant values in society and also play an essential role in the shaping of our perspectives. Ideally, Canadian cinema aims to foster and promote the telling of Canadian stories to Canada and the world (Lam, forthcoming). However, Canadian cinema has not had the same significance to Canadians as Hollywood has had with its American counterparts. Indeed, Hollywood - with its vast economic resources, the glitz and glamour of the star system as well as the high production values - attracts international audiences and has appealed to Canadians more than their own domestic film industry (Melnyk, 2014). Interestingly, what distinguishes Canadian cinema from other national cinemas is a focus on particular -places and "national myths that grow out of people's shared experiences of history and geography," all of which are circulated and then developed in the national culture (Giannetti and Leach, 2008, p. 318). Within Canadian national cinema, audiences view places that draw attention to the shared experience of being within these geopolitical, socio-spatial locations. Such experiences, embodying Canadian culture, are replicated on screen, and demonstrate how shared meanings of culture are (re)produced in Canadian films. Giannetti and Leach (2008, p. 318) claim that what is more important than conscious attempts to construct or define a national identity are "the indirect, and often inadvertent, ways in which films reflect the traditions and cultures of the nations in which they are made." Consequently, this paper contends that crime films set in Winnipeg, a city situated in the centre of North America, reflect and contribute to place myths and cultural identity of the city within the national imaginary. Place-myths have the potential to construct meanings about a particular place, indicating whether it is romantic or dangerous, progressive or "backward," vibrant or decaying. In this sense, placemyths are in many ways akin to cultural stereotypes (Shields, 1991, p. 68). While currently branded by local civic boosters as the 'Heart of the Continent,' (Kives, 2008) the construction of Winnipegas-place on film tells a different tale.

This paper begins by first establishing how theoretical conceptions of place, such as Cresswell's (1996) and Thrift's (2003) focus on place, impact how place-myths manifest within Canadian crime film narratives. Second, the paper examines Winnipeg as a 'city place' including the cityscape's signs, landmarks and geography and the 'North' identity that has become synonymous with the Canadian identity at large (Shields, 1991; Grace, 2007). Indeed, the city's official slogans over the course of the last several decades speak to how the promotion of the 'city place' continues to be viewed as a vital component of economic development for Winnipeg (Lehr and Zubrycki, 2012). Finally, as a 'frozen place', there is little Winnipeg can do to counter the reality of its severe winter climate (ibid). Perceived as "damn cold," Winnipeg is characterized by a climate that predetermines the routines and lifestyles of those that inhabit the cityscape (ibid, p. 65). It is important to differentiate between the notions of 'white' and 'White' onscreen, as the former refers to the colour while the latter refers to the racialized identity of the majority of protagonists. On film this is shown through the reoccurrence of 'white', snowy spaces and the policing of such spaces. However, 'white' spaces are not solely represented in terms of snowcovered landscapes. Such spaces symbolize the hegemony of 'White', Canadian Anglophone men in film, as in the city, and the marginalized place of non-white characters and Indigeneity (with the notable exception of Stryker) on screen. In essence, the (re)presentation of Winnipeg-as-frozen place culturally frames the city as a northerly outpost where civilization ends and where justice rarely prevails against both the forces of nature and for the racialized 'Others' who live there. 


\section{A Brief Note on Methodology}

We implement a qualitative media analysis (Altheide and Schneider, 2013) in order to highlight the unique attributes of Winnipeg that inevitably reappear on film. As Altheide and Schneider (ibid, p. 25) suggest, it is important to construct a protocol that guides data collection for each film under analysis. Our subsequent protocol focused initially on the narrative structure of each film, as well as the setting; the lighting, sound, and set scenery; characters' movements onscreen; and camera angles. We then performed data coding to conceptually refine and determine the themes that arose our data analysis - namely, the emergent themes from each film separately and from the films collectively (ibid; see also Giannetti and Leach, 2008). The films were all shot on location in the city of Winnipeg. Furthermore, Winnipeg plays itself in these films, rather than standing in for another American city, as is often the case. Offering stories about crime and criminality, these films depict a city whose cinematic representations remain relatively underexplored (Bookman and Gacek, forthcoming).

The films analyzed in this paper are read as Canadian crime films, defined as films that depict as a significant theme, crime and its consequences in Canadian society (Kohm, Bookman and Greenhill, forthcoming) and draw on frozen, winter motifs to supplement such a theme. However, as Valverde (2006, p. 32) contends, we are reminded that there cannot be a "universally useful method" when analyzing law and order representations and images. Reliability, validity, replicability, and the ability to predict and forecast future events - while not wholly irrelevantare methodological concerns and are rarely and directly useful "for the purposes of qualitative analyses of what are often unique sets of signs" (ibid). Nevertheless, our research contributes to the literature on Canadian film studies by filling the literature gap concerning Canadian shared meanings and Canadian places that repeatedly proliferate such embodied experiences (Melnyk, 2014; Bookman and Gacek, forthcoming; Lam, forthcoming). We selected films set in Winnipeg that conform to Nicole Rafter's (2006: 6) definition of crime films: "films that focus primarily on crime and its consequences." In particular, we included only those Winnipeg crime films that engage the common place myth of Winnipeg as a frozen and wintery city. Thus, we excluded films that either lacked significant focus on crime and its consequences, such as Guy Madden's celebrated film My Winnipeg (2007), as well as films that were not set during a Winnipeg winter such, as John Paizs' Crime Wave (1985) or Zeyda and the Hitman (2004). Our analysis of Stryker (2004), Mob Story (1989), Seven Times Lucky (2004), and High Life (2009) incorporates sociospatial and cultural criminological scholarship into an analysis of film in an attempt to diversify and broaden the field of knowledge within Canadian film studies. These feature-length films were selected for analysis because of their repeated use of Winnipeg neighbourhoods and streetscapes, the centrality of crime and its consequences in the narrative, and importantly, their incorporation of Winnipeg's harsh winter climate into each respective storyline.

\section{Theorizing Place}

Contemporary literature suggests that researchers investigating places in society must take into account how and why individuals and/or groups in society become attached to particular places (Pollini, 2005; Dahl and Sorenson, 2010; Raymond et al., 2010; Rollero and De Piccoli, 2010; Lewicka, 2011; Cassiers and Kesteloot, 2012). In addition, researching the shared meanings of experiences becomes essential to place identification and the ways in which such individuals and 
groups construct their sense of selfhood from places (Stedman, 2002, 2003; Kyle et al., 2004; Hernández et al., 2007; Hernández et al., 2010).

'Place-myths' play a significant role in social spatialization (Shields, 1991), which may conflict with the branding of the place that is sustained and carried out by entrepreneur coalitions and business interests, local governments, and media (Greenberg, 2008; see also Jayne, 2006). Social spatialization designates "the ongoing social construction of the spatial at the level of the social imaginary (collective mythologies, presuppositions) as well as interventions in the landscape (the built environment)" (Shields, 1991, p. 31). Place-myths resonate with Rafter's (2006) assertion that myths are ideological and refer to the "fundamental notions that people hold (usually without much conscious thought) about how the world is structured, what is valuable and unworthy, who is good and who is bad, and which kinds of actions are wrong or right" (p. 9). As Creswell states, places - and the landscapes that encompass them - are "ideas set in stone that, like it or not, we have to act in. Our actions are interpretations of the text of a place that are recognizable to other people and thus reinforced" (Cresswell, 1996, p. 157, emphasis added). In this regard, how characters on film perform in places becomes recognizable to audiences that reinforce and reaffirm the performance in how they use and understand these and similar places. Bookman and Gacek (forthcoming) suggest that three key place-myths establish and circulate within Winnipeg: Winnipeg as a blue collar city, a stagnant place that is stuck in time and a divided multicultural city. The repeated imagery in Winnipeg crime films of older, inner-city neighbourhoods and streets, the North End rail yards, former factories and abandoned warehouses, machine shops, as well as low-end hotels and motels form the backdrop for criminal activity and are entangled in depictions of crime as masculine as well as working class.

Cresswell (1996) contends that in order to unravel and examine the qualities of place, researchers must describe places in terms of three elements: location, locale, and sense of place. A set of coordinates provides a location (i.e. a café as a point in space). Additionally, while the locale refers to "a broader context for social relations," (p. 156) sense of place refers to "the subjective feelings associated with a place" (p. 156). It is this sense of 'being there' that becomes the focus for cultural and human geographers alike. By incorporating the notion of a symbolic relationship between person and place, and involving perceptions of qualities that imbue places with a particular character (Peterson and Saarinen, 1996), the image of a place becomes the sum of ideas, beliefs and impressions that people have of a place and that (re)present "a plethora of associations and pieces of information that are connected with that place" (Lehr and Zubrycki, 2012, 51; see also Kotler et al., 1993). Moreover, the routines and practices found within these places create meanings that, when taken into consideration with others' feelings of 'being there,' permit shared meanings of experience to proliferate the place as a whole.

Combining Cresswell's understanding of place with Thrift's (2003) focus on "place space" provides researchers insight into how place can be investigated further. According to Thrift (2003), "place space" centers on the notion that certain spaces are more 'human' than others, and that certain places permit bodies to live out more easily "a particular Western idea of what human being should be being" (p. 102). Specifically, place space consists of "particular rhythms of being" that confirms, naturalizes and evokes particular embodiments, emotions, memories, and the existence of certain spaces (p. 102). As Soja (1989) argues, spatiality is socially (re)produced and, like society itself, exists as an "'embodiment' and [as a] medium of social life" (p. 120). 


\section{Winnipeg Crime Films}

The first film, Stryker, tells the tale of an Aboriginal boy who leaves his reservation in the hopes of a better life in Winnipeg. Unfortunately, Stryker becomes caught up in the middle of two rival gangs: the Indian Posse and the Asian Bomb Squad. The gangs are in a war over Winnipeg's North End, a neglected inner-city neighbourhood. A second film, Mob Story, centres on Luciano (Luce), a mob boss living a luxurious lifestyle in New York City. However, in an attempt escape the watchful eye of the "feds," Luce takes a plane to Winnipeg, instead of heading to Palm Springs. To his surprise, Luce arrives in the cold, wintry Winnipeg. Inevitably he becomes embroiled in the local crime scene to save his son and his ex-lover as well as their family business. In the third film, Seven Times Lucky, we follow a conman named Harlan. Harlan is always looking for the next opportunity to score big in the illicit goods market. However, in order to settle his debts by Christmas Eve, he becomes tangled up with a number of characters (such as a pawnbroker, a wealthy tribal fund manager, and a handful of petty criminals) and their schemes. Finally, High Life is set in 1983, just after the birth of the Automated Teller Machine (ATM). High Life is a story of loyalty, honour and kinship amongst a group of four thieves. In a downtown hospital, a visit from his former sociopathic cellmate Bug had led to Dick (the main protagonist of the film) to be fired from his job as a janitor. Unemployed and in desperate need of money, Dick decides to rob one of the new ATMs at Meyer Bank in order to "buy a little self-respect". The other two members of the crew include Donnie, a criminally minded identity thief; and Billy, a promiscuous, sleepyeyed charmer of women. Unfortunately, things do not go according to plan, as an employee of the bank double-crosses the team. In the end, the unfolding of alternately tragic and comedic events tests the friends' loyalties as their plan for quick riches results in the deaths of Bug and Billy and the imprisonment of Dick.

With the exception of Stryker, these films fall into the category of "traditional crime films" that follow "the usual moral pattern of which is violation, discovery, punishment, and resolution" (Rafter 2006: 74; see also Bookman and Gacek, forthcoming). Following the "alternative tradition" of critical crime films, Stryker does not rely on "pat endings and feel-good morals" (Rafter 2006: 74). Instead, the criminal activity of gangs goes unpunished as Indian Posse declares victory over the Asian Bomb Squad. Indeed, Stryker ends with a scene of Stryker, escorted to the city limits by police, solemnly gazing at the Winnipeg skyline, with cuts to shots of bison grazing on the winter prairie. The film's opening sequence resembles this final scene, and in so doing does not offer resolution. Alternatively, Stryker invites audiences to ponder broader societal issues, such as Aboriginal justice and the social divisions affecting Winnipeg.

\section{A 'City Place' and a 'Cold Climate': Winnipeg and the 'North' Identity}

When an audience views the setting of a film, almost indirectly the place itself attempts to appear through the usage of signs that are native to its location. While recognition varies amongst films, some cityscapes like Paris, London, and New York City exist as iconic places that have no difficulty in promoting itself on the silver screen. Yet, what makes these places stand out amongst other cities in the world? What makes Winnipeg stand out on film to audiences? What identifiers exist in the real world that permit audiences to recognize this cityscape?

After examining the aforementioned crime films, it appears that particular infrastructural signs and Winnipeg's architectural legacy consistently (re)appear on screen. There is overlap between films, in the sense that one infrastructural sign may appear in more than one film to 
represent Winnipeg. The Arlington Bridge, a bridge that connects Downtown Winnipeg to the 'North End' neighborhood, is a piece of infrastructure that is used repeatedly in Stryker and High Life. As well, the Garrick Hotel - a hotel that is now a heritage building in the city - is shown in films such as Horsemen, High Life and Seven Times Lucky. Finally, Main Street and Selkirk Avenue are two inner city streets that frequently used in transition scenes that involve tracking shots (i.e. shots that are taken from a dolly or a truck and filmed in motion). Examples of such tracking shots include the scene where Luciano and Tom (Luciano's son) are driving down Selkirk Avenue in Mob Story (as well as a car chase scene down Main Street), and when Harlan visits Eddie's illicit goods store on Selkirk Avenue in Seven Times Lucky.

Another theme that is shown across the crime films is how the cityscape both constructs and impacts the 'North' identity that can be seen in Canadian society at large. In a sense, what it means to adhere to 'Northernness' implies that, as Shields (1991) contends, for most Englishspeaking Canadians, the idea of 'North' is not just "a factual geographical region but also an imaginary zone: a frontier, a wilderness, an empty 'space'" (p. 165). While the study of the 'North' is not new to Canadian studies (Shields, 1991; Grace, 2007; de la Barre, 2013), the focus on the frontier is significant in relation to the intersecting themes of crime and place that appear in Canadian cinema. Arguably, if "[i]dentity freezes the gesture of thinking," (De Certeau, 1986, p. 194; emphasis added) then it is correct to say that a 'North' identity substantiates the feelings, experiences and bodily sensations that Canadians - and Winnipeggers, more specifically — undergo when they immerse themselves in the environments (both the urban and the frontier) that pervade Canadian cinema. Winnipeg's North End neighbourhood is a clear example of such environments, as for outside observers, the North End of Winnipeg is "Canada's quintessential land of despair, where the seedy bars of the North Main street empty into an area of poor-quality housing, low educational attainment, high unemployment, and visible poverty" (Hiebert, 1992, p. 92; see also Rowley, 1978; Hiebert, 1991; Lehr and Zubrycki, 2012).

Therefore, what constitutes a 'North' identity in terms of a Canadian and Winnipeg context? Shields (1991) suggests that central to Canadian myths vis-à-vis socio-spatiality entails the myth of the "True North Strong and Free" (p. 162, see also Grace, 2007 regarding the "True North' identity). This notion is appropriated as one symbolic identity within English-speaking Canadian nationalistic discourse, in which Canada itself is a frozen, "resource and economic hinterland" that is concomitantly incorporated in a social spatialization as a mythic, cultural heartland (ibid, p. 163). A phrase from the English version of the Canadian national anthem, 'True North Strong and Free' harnesses the physical datum of the 'North' - such as 'truth, purity, freedom, [and] power" (ibid, p. 164). A 'North' identity exudes a resilience to the geographical elements, and a perseverance to achieve the great riches and opportunities that the Frontier can offer, much to the same extent as the fur traders, hunters and pioneers that first settled in Canada historically (Brody, 1987; Shields, 1991; Grace, 2007; de la Barre, 2013). The idea of crossing the Frontier, then, is central to the cinematic exploration of crossing boundaries and differences between 'civilized' society and the freedom or disorder found in the wilderness, of the "paradise that lies beyond" (O'Shaughnessy and Stadler, 2005, p. 211). Furthermore, the North End landscape reflects the importance of ethnic and racial diversity, as this landscape is punctuated "by churches, halls, and small-scale ethnic businesses. Main Street and Selkirk Avenue are the area's two commercial thoroughfares... [and the] the southwest portion of Main is dominated by hotels and bars and is reminiscent of the wild-west atmosphere of Winnipeg's early days" (Hiebert, 1992, p. 96. Italics in original). By incorporating traits of the frontier into the cityscape, Winnipeg (and the North End) on film appears both as a "place of recreative freedom" (Shields, 1991, p. 191) and 
as a distinctive city that is "miraculously alive... in the grey desolation" (Marlyn, 1957, p. 220, cited in Hiebert, 1992, p. 97). In turn, such frontier traits pose a threat to the ordered structures of Canadian society at large.

Since the 1980s onwards, Winnipeg has had a terrible reputation as " damn cold' and a city that had many down-and-out drunks hanging around Main Street" (ibid, p. 65; see also Squire, 1986). Such a reputation suggests that the cold climate of Winnipeg exists as a stagnant city. Indeed, as a city that is stagnant and 'frozen' in time, Winnipeg seems to offer little in the way of legitimate opportunities for advancement in work or life (Bookman and Gacek, forthcoming). Moreover, this chilly climate could convince anyone to leave the cityscape, yet what is important to note is the body language of the main characters that is relatable to the audiences that inhabit cities experiencing similar conditions to Winnipeg. When the audience sees the characters shiver in the icy winds and the winter chill, these films attempt to forge a connection to audiences through their own bodily experiences. As Clare (2013) argues, bodily sensations, such as the sensation of temperature, indexes "a quality of our encounter with the world as we live and act in it" (Clare, 2013, p. 174, emphasis added). In this sense, the audience as social actors and the characters as physical actors on screen can be linked through their affirmation of each other's experiences. In other words, the audience affirms the characters' visible sensations of coldness, and in turn the characters affirm the audiences' experiences of coldness by presenting bodily sensations visually on screen. The fact that the place of Winnipeg is used to reinforce this relationship merely oscillates the relationship between the audience and the characters-on-screen further, inevitably forging a stronger emotional connection between the former to the latter and vice versa.

\section{A Frozen 'Urban' Space}

As Ferrell and colleagues (2008) have previously noted, the analysis of urban space and its underlife runs throughout cultural criminological literature (see also Hayward and Young, 2004; Hayward, 2010). Suffused by rules and regulations, the urban city nonetheless "remains a place where transgression occurs" (p. 80) and the ability to bend the rules becomes negotiated with the citizens that inhabit the cityscape.

Winnipeg on film is represented as a place of transgression, in which the rules of law, order and justice are contested, negotiated, and resisted by the main characters. In a phone conversation between Luciano and Sam - the former being the protagonist of Mob Story while the latter is the antagonist - Luciano explains to Sam that in order to successfully hide out in Winnipeg until the suspicion from 'the Feds' goes away, Sam (who is at this point in the film Luciano's second-incommand of Luciano's crime mob organization) must not follow Luciano to Winnipeg. Luciano states that he "[wouldn't] recommend that you come into Winnipeg Sam, it's a real killer."

As a 'real killer,' Winnipeg on film contests law, order, justice and crime, as it almost appears to be the 'real' antagonist within Canadian crime films and has an omnipotent presence on screen. This is shown through the white winter landscapes, as the omnipresence of white has been suggested to imply symbolic death (Shields, 1991; Grace, 2007). As Grace (2007) points out, "the qualities of snow, ice, extremes of cold, isolation, space, silence, austere beauty, and dread" are all qualities we experience as northern and uniquely Canadian (p. 125). Yet the 'recreative freedom' of winter is both beautiful and horrific (i.e. 'chilling') as the chaos of such recreative freedom on screen - the panning shots of the vast urban sprawls and remote winter landscapes, coupled with the close-up shots of protagonists juxtaposed with the blurred distinctions of winter foregrounds and backgrounds - suggests that the tensions between protagonists, antagonists and the narrative 
can only be resolved by a character undergoing "a symbolic death and re-creation of him- or herself" (Shields, 1991, p. 191). An example of this would be the final scene in Stryker where Stryker is abandoned on the outskirts of Winnipeg by a police officer.

While in Mob Story Luciano makes a statement in reference to Tom's life expectations for the future (see the start of this section), this statement can be indicative of the place in which such opportunities unfold for its inhabitants. In other words, as a 'frozen place,' Winnipeg is a cityscape that appears timeless and resistant to change on film. While characters try to achieve higher socioeconomic statuses, life opportunities, and to "buy a little self-respect" for themselves (Dick, High Life), from a cinematic perspective, the setting of winter repeatedly used throughout the crime films suggests that Winnipeg as place takes on a life of its own and attempts to reassert a dominance on screen by the reinforcement of winter and freezing temperatures. Inevitably, the mountains of snow, icy winds and tundra-like conditions of the city suggests to the audience that greater life opportunities within this cityscape are possible insofar as the city permits them to occur.

\section{'Frozen Justice' and 'Frontier Justice'}

As mentioned earlier, the 'recreative freedom' of the North works into the vastness of the space and weakens the attachment with the urban spaces of the city. While many criminal activities involve danger and risk-taking, the act of criminality can represent an attempt to break free of one's demeaning and restraining circumstances, "to exercise control and take responsibility for one's destiny" (Jewkes, 2004, p. 29). The proximity between urban and frontier spaces are important to consider, as proximity has both cultural and spatial dynamics - while cultural proximity refers to an event's 'relevance' to an audience, a spatial proximity indicates an event's geographical 'nearness' (Jewkes, 2004). These factors intertwine when we examine the proximity between urban and frontier spaces, in which the journey from the urban to the frontier reinforces a greater physical distance between the two spaces.

The extent of this detachment from law, order and justice is shown in Stryker, Horsemen and High Life, as the rural, wintry landscapes that the protagonists travel to indicate both a greater distance from Winnipeg and a greater indication of heinous criminality. In Stryker, Stryker is taken to the outskirts of Winnipeg and physically assaulted by a police officer; and in High Life, Bug tries to escape on horseback from a deserted ranch Bug and Dick have come across, but the gun fired intentionally into the air by Dick scares Bug's horse and throws Bug off, killing Bug instantly.

The escape from the 'civil' society's constraints to journey to rural landscapes means that freedom, then, has the potential to reinforce self-reliance. Living life "outside the law" (O'Shaughnessy and Stadler 2005, p. 211, emphasis added) forms the basis then upon which vigilante or 'frontier' justice supersedes law and order. Law - and arguably, order - cannot be everywhere at once because state and local legal actors - such as municipal police, Royal Canadian Mountain Police (RCMP), lawyers and so forth - cannot be everywhere at once (Pruitt, 2014). 'Frontier justice' is more than just simply vigilantism - it is vigilante justice within the cultural context of association or belonging to a particular social group. Frontier justice on film appears as modified or altered law and order constituted in the urban space, in which it polices those individuals that journey from urban spaces, and surveying them from 'outside the law' of the urban, constructs new culturally shared meanings of law and order. Frontier justice pushes the physical and cultural boundaries of criminological knowledge into terra nova by questioning and evaluating preconceptions of crime, incorporating the "dangerous knowledges" that are discovered when we leave the familiar 'civilized' society we know (Hayward and Young, 2004). 
Moreover, frontier justice goes further by 'responsibilizing' individuals to fend for themselves and instructs them to take the law into their own hands (see also Gonzales-Day, 2006). Emphasis on the 'rural highways' - that is, where the rural or frontier spaces were established for heinous crimes in Stryker, Horsemen and High Life - indicates that in the case of Winnipeg, frontier justice begins by operating in terms of one travelling to such spaces on the periphery of Winnipeg. By travelling to the cusp of 'civil' society, what exists is an alternative justice system that enacts draconian punishments and odious consequences for disobeying the rules of the frontier-for example, the 'starlight tour' Stryker is taken on by the police officer in Stryker, and the bloody teeth served on a silver platter out on a frozen pond in Horsemen. A 'chilling' structure of feeling is evoked through film as a result-one that centers on the shared experience of living through Winnipeg's cold climate. In effect, the move from the city suggests that perhaps protagonists are attempting to escape the 'stagnant place' of Winnipeg. With references to its cold, snowy winters and landscapes, frontier justice appears 'frozen' onscreen, suggesting that the symbolism of snow and ice construct a notion of Winnipeg as perpetually "frozen" in time. Inevitably, frontier justice on film appears as 'frozen' justice - that is, a frontier justice system deeply rooted in tradition, stasis, and incapable of changes to its system for fear of abhorrent results.

Moreover, multiple and overlapping representations of 'whiteness' (re)occur within this structure-namely, the snow-covered landscapes, the horrific (i.e. 'chilling') crimes that are committed, and the White, male hero. The predominance of White, English-speaking Canadian men is important to note, as frontier justice appears to run along gendered, racial axes. While the argument for White, masculine spaces has appeared in the literature (Shields, 1991; Grace, 2007; de la Barre, 2013), what has not been discussed is the way in which the gendered, racial axes of spaces permeate frontier justice. Canadian cinema allows for such an understanding in terms of visualizing how the law and order of the cityscape appears inadequate to combat crime and criminality, which in turn affirms the use of self-reliance and frontier justice in these peripheral spaces. In travelling from the urban to the frontier, the characters that make this journey in Stryker and High Life are predominately White and male.

Therefore, the cityscape's justice is represented on film as fragmented and failing, insofar as the legal actors and law enforcement within urban spaces are not qualified to combat the criminality that is (re)appearing within its own boundaries, let alone on the frontier where more heinous criminality occurs. While there is a great deal of scholarly research focusing on racial profiling, the 'usual suspects' phenomenon may be more significant in communities where law enforcement officers are likely to be socially embedded with those whom they police (Pruitt, 2006). It becomes possible, then, to link "the predominance of personal, face-to-face social relationships among similar people" with the reluctance to alter tradition and stasis, both of which are widely associated with the frontier (Willits et al., 1982, p. 70). Situating this understanding in the case of Winnipeg, the city on film is shown as one that tries to absorb the ideals of frontier justice. Characters such as Stryker (originally from Broken Ojibway Nation in Stryker) and Billy (from Montreal in High Life) are immediately distrusted by many of the cast that interacts with them on screen. While they are permitted to enter into the masculine spaces of the cityscape on screen, their racial/ethnic backgrounds (i.e. the Aboriginal background of Stryker and the French background of Billy) are consistently brought up in dialogues with the characters themselves. In effect, the presence of Stryker and Billy increases the level of distrust amongst the groups they interact with (i.e. IP and ABS in Stryker, and Dick's crew in High Life, respectively) and an increase in reluctance to accept them into the society of the cityscape. Consequently, the imaginative geography of Winnipeg combines aspects of the urban and rural to construct a place-myth that 
upholds White, masculine spaces and interactions while 'Other-ing' those individuals in the process.

\section{Concluding Remarks}

As Rob Shields (1991, p. 39) suggests, "[c]onceptions of space-which are central to any ontology - are part and parcel of notions of reality." One's relationship with the world results from the fundamental component to one's spatiality and sense of space. A sense of place is significant to consider when we contextualize shared meanings in Canadian film, as one's sense of space can only constellate when one's experiences of being and acting within a place is taken into account. Winnipeg ultimately becomes represented on film as a place where crime is rampant and law enforcement is unable to combat both the criminal behaviour within the city - in other words, where law and justice is 'frozen.'

By implementing a qualitative media analysis, we have argued that place-myths manifest themselves within Canadian crime film narratives, and that a better understanding of place allows us to observe how Winnipeg becomes socially spatialized onscreen. As a 'city place', the 'North' identity has greatly entrenched itself within the city's several slogans over the course of the last several decades (Lehr and Zubrycki, 2012). As a 'frozen place', Winnipeg's place-myths suggest that climate predetermines the lifestyles of the citizens that inhabit the city's severe winter climate. Shown through the reoccurrence of White, male spaces and the further policing of such spaces, we have witnessed how 'White' spaces are not solely represented in terms of snow-covered landscapes, but in terms of the traditions rooted within the city's culture that make Winnipeg appear stagnant, 'stuck' in time, and 'frozen' overall. Indeed, the (re)presentation of Winnipeg in Canadian crime film suggests that there is a far more complex relationship between the 'frozen' and the 'frontier' aspects of the cityscape. Frontier justice both constructs and reflects frozen justice and that by culturally framing Winnipeg as a northernly outpost, what audiences view onscreen are the placemyths at work: a 'frozen' city at the edge of the civilization's end, where justice rarely prevails against both the forces of nature and the racialized 'Others' living within them, and where winter consumes all who inhabit this place.

This study has forged a connection between place and film studies, and shows how the cold climate of the cityscape contributes to the place-myths at work. By using the case study of Winnipeg, it becomes possible to charter other investigations concerning how places are (re)imagined and (re)presented on the silver screen. Canadian cinema-specifically Canadian crime films - permits researchers to further investigate the link between Canadian shared meanings and places that repeatedly proliferated through embodied experiences. Investigating sociospatiality vis-à-vis criminality extends and diversifies the field of knowledge and subsequent knowledge production within Canadian film studies.

\section{About the authors}

James Gacek is currently a student at the Edinburgh Law School, University of Edinburgh. He received his MA in Sociology from the University of Manitoba. He can be reached at J.Gacek@sms.ed.ac.uk

Dr. Steven Kohm is an associate professor in the department of Criminal Justice at the University of Winnipeg. He can be reached at s.kohm@uwinnipeg.ca 


\section{References}

Altheide, D. L. \& Schneider, C. J. (2013). Qualitative Media Analysis. (2 ${ }^{\text {nd }}$ Ed.). London, UK: Sage Publications Ltd.

Ball, J. (2014). John Paizs's Crime Wave. Toronto, CAN: University of Toronto Press.

Bookman, S. \& Gacek, J. (Forthcoming). Screening Justice: Canadian Crime Films and Society (Winnipeg, MB: Fernwood Publishing).

Brody, H. (1987). Living Arctic: Hunters of the Canadian North. Toronto, CAN: Douglas and McIntyre.

Cassiers, T. \& Kesteloot, C. (2012). Socio-spatial Inequalities and Social Cohesion in European Cities. Urban Studies 49, 9, 1909-1924.

Clare, S. (2013). Feeling Cold: Phenomenology, Spatiality, and the Politics of Sensation. differences: A Journal of Critical Feminist Studies 24, 1, 169-191.

Cresswell, T. (1996). In Place/Out of Place: Geography, Ideology, and Transgression. Minneapolis: University of Minnesota Press.

Crime Wave. Dir. John Paizs. Perf. John Paizs, Eva Kovacs. Favorite Films 1985. VHS.

Dahl, M. S. \& Sorenson, O. (2010). The Social Attachment to Place. Social Forces 89, 2, 633 658.

De Certeau, M. (1986). Heterologies: Discourse on the Other. Minneapolis, MN: University of Minneapolis Press.

De la Barre, S. (2013). Wilderness and cultural tour guides, place identity and sustainable tourism in remote areas. Journal of Sustainable Tourism 21, 6, 825-844.

Ferrell, J., Hayward, K. \& Young, J. (2008). Cultural Criminology. Los Angeles, CA: Sage Publications Ltd.

Gianetti, L. \& Leach, J. (2008). Understanding Movies. Toronto, CAN: Pearson Prentice Hall.

Grace, S. E. (2007). Canada and the Idea of North. Montreal and Kingston, CAN: McGillQueen's University Press.

Greenberg, M. (2008). Branding New York: How a City in Crisis was Sold to the World. New York, NY: Routledge.

Gonzales-Day, K. (2006). Lynching in the West 1850-1935. Durham, NC: Duke University Press. 
Hayward, K. J. \& Young J. (2004). Cultural criminology: Some notes on the script. Theoretical Criminology 8, 3, 259-273.

Hayward, K. J. (2010). Opening the lens: Cultural criminology and the image. Pp. 1-16. In Framing Crime: Cultural Criminology and the Image, edited by Keith J. Hayward and Mike Presdee. New York, NY: Routledge.

Hernández, B., Hidalgo, C. M., Salazar-Laplace, E. M. \& Hess, S. (2007). Place attachment and place identity in natives and non-natives. Journal of Environmental Psychology 27, 4, 310-319.

Hernández, B., Martin, A. M., Ruiz, C. \& Hildago, C. M. (2010). The role of place identity and place attachment in breaking environmental protection laws. Journal of Environmental Psychology 30, 3, 281-288.

Hiebert, D. (1991). Class, ethnicity and residential structure: the social geography of Winnipeg, 1901-1921. Journal of Historical Geography 17, 1, 56-86.

-------. (1992). Winnipeg's North End. The Canadian Geographer 36, 1, $92-97$.

High Life. Dir. Gary Yates. Perf. Timothy Olyphant, Stephen Eric McIntyre, Joe Anderson, Rossif Sutherland. Union Pictures 2009. DVD.

Horsemen. Dir. Jonas Åkerlund. Perf. Dennis Quaid, Ziyi Zhang. Lionsgate 2009. DVD.

Jayne, M. (2006). Cities and Consumption. New York, NY: Routledge.

Jewkes, Y. (2004). Media \& Crime: Key Approaches to Criminology. London, UK: Sage Publications Ltd.

Kives, B. (2008, September 6) Winnipeggers say they're Heart of the Continent. Winnipeg Free Press.

Kohm, S. A., Bookman, S. \& Greenhill, P. (Forthcoming). Screening Justice: Canadian Crime Films and Society (Winnipeg, MB: Fernwood Publishing).

Kotler, P., Haider, D. \& Rein, I. (1993). The Geography of Nowhere: The Rise and Decline of America's Man-Made Landscape. New York, NY: Touchstone.

Kyle, G., Graefe, A., Manning, R. \& Bacon, J. (2004). Effects of place attachment on users' perceptions of social and environmental conditions in a natural setting. Journal of Environmental Psychology 24, 2, 213-225.

Lam, A. (Forthcoming). Screening Justice: Canadian Crime Films and Society (Winnipeg, MB: Fernwood Publishing). 
Lehr, J. C. \& Zubrycki, K. (2012). Image-building in Manitoba. Pp. 49-91. In Image-Building in Canadian Municipalities, edited by Jean Harvey and Robert Young. Montreal, QC: McGill-Queen's University Press.

Lewicka, M. (2011). Place attachment: How far have we come in the last 40 years? Journal of Environmental Psychology 31, 207-230.

Melnyk, G. (2014). Film and the City: The Urban Imaginary of Canadian Cinema. Edmonton, CAN: AU Press.

My Winnipeg. Dir. Guy Maddin. Perf. Darcy Fehr, Ann Savage, Louis Negin. Buffalo Gal Pictures 2007. DVD.

Mob Story. Dir. Gabriel Markiw, Jancarlo Markiw. Perf. John Vernon, Kate Vernon, Al Waxman, Margot Kidder. Brightstar Pictures 1989. DVD.

O’Shaugnessy, M. \& Stadler, J. (2005). Media and Society: An Introduction. Oxford, UK: Oxford University Press.

Peterson, G. \& Saarinen, T. (1986). Local Symbols and Sense of Place. Journal of Geography, $85,4,164-168$.

Pollini, G. (2005). Elements of a Theory of Place Attachment and Socio-Territorial Belonging. International Review of Sociology 15, 3, 497-515.

Pruitt, L. R. (2006). Rural Rhetoric. Connecticut Law Review 39, 1, 159-240.

Pruitt, L. R. (2014). The Rural Lawscape: Space Tames Law Tames Space. Pp. 190-214. In The Expanding Spaces of Law: A Timely Legal Geography, edited by Irus Braverman, Nicholas Blomley, David Delaney, and Alexandre Kedar. Stanford, CA: Stanford University Press.

Rafter, N. (2006). Shots in the Mirror: Crime Films and Society. New York, NY: Oxford University Press.

Raymond, C. M., Brown, G. \& Weber, D. (2010). The measurement of place attachment: Personal, community, and environmental conditions. Journal of Environmental Psychology 30, 422-434.

Rollero, C. \& De Piccoli, N. (2010). Place attachment, identification, and environment perception: An empirical study. Journal of Environmental Psychology 30, 198-205.

Rowley, G. (1978). Plus ça change: A Canadian skid row. The Canadian Geographer 22, 211224. 


\section{CGJSC / RCESSC}

Vol. 5 - Issue 1/ No. 1 - Summer / été 2016

Seven Times Lucky. Dir. Gary Yates. Perf. Kevin Pollack, Liane Balaban. Buffalo Gal Pictures 2004. DVD.

Shields, R. (1991). Places on the Margin: Alternative Geographies of Modernity. London, UK: Routledge.

Soja, E. (1989). Postmodern Geographies: The Reassertion of Space in Critical Social Theory. London, UK: Verso Press.

Squire, S. J. (1986). Boosterist Landscapes and the Geography of Community Promotion: An Analysis of the Western Canadian Experience. BA diss., University of Winnipeg.

Stryker. Dir. Noam Gonick. Perf. Kyle Henry, Deena Fontaine, Ryan Rajendra Black. Julijette 2004. DVD.

Valverde, M. (2006). Law and Order: Images, Meanings, Myths. New Brunswick, NJ: Rutgers University Press.

Willits, F. K., Bealer, R. C. \& Crider, D. M. (1982). Persistence of Rural/Urban Differences. Pp. 69-76. In Rural Society in the US: Issues for the 1980s, edited by Don A. Dillman and Daryl J. Hobbs. Boulder, CO: Westview. 